\title{
Hydraulic properties of horticultural substrates
}

\author{
Uwe Schindler $^{1^{*}}$ and Frank Eulenstein ${ }^{1}$ \\ ${ }^{1}$ Mitscherlich Academy for Soil Fertility (MITAK), Professor Mitscherlich Allee 1, D14641 Paulinenaue. \\ *email: schindler@mitak.org
}

\begin{abstract}
One main criterion for evaluating the suitability of horticultural substrates for horticultural applications is their capability to store and transport water. The basic substrate hydraulic variables which provide this information are the water retention curve and the unsaturated hydraulic conductivity function. Substrate shrinkage and water repellency are of similar importance. A set of 36 commercial horticultural substrates was selected and the hydraulic properties (water retention curve, unsaturated hydraulic conductivity function, capillary rise and shrinkage) were measured with the Extended Evaporation Method (EEM). Additionally, the water drop penetration time was determined as a measure of wettability. Here the raw data are presented. Data access:

http://dx.doi.org/10.4228/ZALF.2015.278
\end{abstract}

Keywords: Horticultural substrates, growing media, extended evaporation method, HYPROP, water retention function, unsaturated hydraulic conductivity, shrinkage, water drop penetration time.

1 INTRODUCTION: Many different horticultural substrates for horticultural applications are on the market. The declaration on the package generally provides information on the ingredients and the chemical composition. Generally water storage evaluations and water budget declarations on substrate packages are based on assumptions or are missing. However, accurate substrate hydraulic criteria, parameters and measurement data can improve the evaluation of the hydraulic performance of these substrates in horticulture (Raviv and Lieth, 2008).

Generally the sand box method is used to measure the water retention curve of horticultural substrates (Raviv and Lieth, 2008, Al Naddaf et al., 2011, DIN EN 13041, 2012). Only a few unsaturated hydraulic conductivity measurements in substrates are presented, but they are substantially required for an overall substrate evaluation (Heiskanen, 1995, Raviv and Leith, 2008). In some cases the onestep-outflow-method was used (Bibbiani et al., 2014, Caron et al., 2014). These methods are timeconsuming, the equipment is expensive and the results are affected by uncertainties (Schindler et al., 2010). Raviv and Lieth (2008) concluded, that there is a lack of standard technologies and methods for the characterization of growing media in horticulture.

The aim of this study was to test the extended evaporation method (EEM) for quantifying the hydraulic properties (the water retention curve, the unsaturated hydraulic conductivity function and the shrinkage dynamics) of horticultural substrates. The data were used as basis for evaluating the effect of the substrate ingredients and composition on the hydraulic performance of the horticultural substrates (Schindler et al., 2015b, Schindler and Müller, 2015a, Schindler and Müller 2015b). The measured raw data provided in this paper are usable for scientists and practicable users.

\section{MATERIAL AND METHOD}

2.1 HYDRAULIC VARIABLES: One main criterion for evaluating the suitability of horticultural substrates for horticultural applications is their capability to store and transport water. The basic substrate hydraulic variables which provide this information are the water retention curve and the unsaturated hydraulic conductivity function. The wetting properties and shrinkage characteristic are of similar importance to the water retention and the hydraulic conductivity of the substrate for the plant water supply. The former are of main relevance for water infiltration and rewetting the substrate. Water repellency and shrinkage could lead to preferential flow and deep drainage as well as solute leaching in soils (Ritsema and Dekker 1996) and substrates (Raviv and Lieth, 2008). They lead to a limited rewetting of the soil and substrate and to water and nutrient stress.

2.2 HORTICULTURAL SUBSTRATES: A set of 36 commercial horticultural substrates (HS) for different horticultural applications was analysed (Table 1). The samples varied in their bog peat and ash content $(\mathrm{x})$, the added ingredients, in their price and other properties. Most substrates consist of $80 \%$ or more bog peat with added mineral and/or organic ingredients (garden residual and compost, forest residual, clay, sand, perlite, coconut fibre, lime, guano). In some substrates there is much less 
bog peat (no. $3,6,25,36)$ and two substrates $(33,34)$ are peat-free. The Chrysal active substrate package (no. 8) provides no information about the ingredients.

Table 1. List of commercial horticultural substrates HS 1 - 36

HS Producer/Market/Product Price Application Ingredients

\begin{tabular}{|c|c|c|c|c|}
\hline 1 & Falkena & M & C & $90 \% \mathrm{Hh}(\mathrm{H} 4-\mathrm{H} 8), 10 \% \mathrm{~T}$ \\
\hline 2 & Plantop & M & C & $\mathrm{Hh}(\mathrm{H} 2-\mathrm{H} 5), \mathrm{G}, \mathrm{F}$ \\
\hline 3 & Plantop, for grass & $\mathrm{M}$ & $\mathrm{F}$ & $35 \% \mathrm{Hh}(\mathrm{H} 2-\mathrm{H} 8), 30 \% \mathrm{~F}, 15 \% \mathrm{G}, 20 \% \mathrm{~L}, \mathrm{~T}, \mathrm{~S}$ \\
\hline 4 & Falkena; rhododendron s. & M & $\mathrm{F}$ & $\mathrm{Hh}(\mathrm{H} 3-\mathrm{H} 9)$ \\
\hline 5 & Falkena, potting soil & M & C & $\mathrm{Hh}(\mathrm{H} 3-\mathrm{H} 8), \mathrm{P}, \mathrm{T}$ \\
\hline 6 & Bodengold, bio substrate & M & $\mathrm{C} / \mathrm{F}$ & $40 \% \mathrm{Hh}(\mathrm{H} 2-\mathrm{H} 8), 20 \% \mathrm{~F}, 40 \% \mathrm{G}, \mathrm{P}, \mathrm{T}$ \\
\hline 7 & Bodengold, premium & M & C & $100 \% \mathrm{Hh}(\mathrm{H} 2-\mathrm{H} 5), \mathrm{P}, \mathrm{T}$ \\
\hline 8 & Chrysal, active soil & $\mathrm{H}$ & C & no information \\
\hline 9 & Cuxin, balcony plants & $\mathrm{H}$ & C & $\mathrm{Hh}(\mathrm{H} 3-\mathrm{H} 7), \mathrm{T}, \mathrm{Co}$ \\
\hline 10 & Cuxin for turf rolls & $\mathrm{H}$ & $\mathrm{F}$ & $\mathrm{Hh}, \mathrm{G}, \mathrm{Co}$ \\
\hline 11 & Falkena, balcony plants & M & $\mathrm{C} / \mathrm{F}$ & $\mathrm{Hh}(\mathrm{H} 2-\mathrm{H} 9)$ \\
\hline 12 & Mecklenburger & KA & $F$ & $\mathrm{Hh}(\mathrm{H} 3-\mathrm{H} 5)$ \\
\hline 13 & Treff_Jiffy Products & $\mathrm{kA}$ & $\mathrm{F}$ & $\mathrm{Hh}(\mathrm{H} 5-\mathrm{H} 8)$ \\
\hline 14 & Plantop, substrate I & M & $\mathrm{C} / \mathrm{F}$ & $80 \% \mathrm{Hh}(\mathrm{H} 2-\mathrm{H} 8), 15 \% \mathrm{~F}, 5 \% \mathrm{G}$ \\
\hline 15 & Thomas Phillips & M & C & $80 \% \mathrm{Hh}(\mathrm{H} 3-\mathrm{H} 7), 15 \% \mathrm{~F}, 5 \% \mathrm{G}, \mathrm{S}$ \\
\hline 16 & Netto supermarket & M & C & $\mathrm{Hh}(\mathrm{H} 3-\mathrm{H} 8), \mathrm{F}, \mathrm{G}$ \\
\hline 17 & Blumenrisse & $M$ & C & $100 \% \mathrm{Hh}(\mathrm{H} 2-\mathrm{H} 8), \mathrm{T}$ \\
\hline 18 & Gartenkrone & M & C & $80 \% \mathrm{Hh}(\mathrm{H} 4-\mathrm{H} 8), \mathrm{F}, \mathrm{P}, \mathrm{Gu}$ \\
\hline 19 & Compo Sana & $\mathrm{H}$ & C & $96 \% \mathrm{Hh}(\mathrm{H} 3-\mathrm{H} 8), \mathrm{P}, \mathrm{Gu}$ \\
\hline 20 & Floragard & $\mathrm{H}$ & C & $100 \% \mathrm{Hh}(\mathrm{H} 2-\mathrm{H} 8), \mathrm{Gu}$ \\
\hline 21 & Fleurelle & M & C & $\mathrm{Hh}(\mathrm{H} 2-\mathrm{H} 6), \mathrm{F}, \mathrm{G}, \mathrm{Gu}$ \\
\hline 22 & Hewita Flor & M & $\mathrm{C} / \mathrm{F}$ & $\mathrm{Hh}(\mathrm{H} 2-\mathrm{H} 6), \mathrm{G}, \mathrm{T}, \mathrm{S}$ \\
\hline 23 & Grüne Welle bio soil & $M$ & $\mathrm{C} / \mathrm{F}$ & $\mathrm{Hh}(\mathrm{H} 2-\mathrm{H} 5), \mathrm{G}, \mathrm{W}$ \\
\hline 24 & Compo Bio universal soil & $\mathrm{H}$ & $\mathrm{F}$ & $\mathrm{Hh}(\mathrm{H} 2-\mathrm{H} 5, \mathrm{H} 6-\mathrm{H} 8), \mathrm{G}, \mathrm{Gu}, \mathrm{Ca}$ \\
\hline 25 & Cuxin, for vegetables & $\mathrm{H}$ & $\mathrm{F}$ & $60 \% \mathrm{Hh}(\mathrm{H} 3-\mathrm{H} 5, \mathrm{H} 5-\mathrm{H} 7), \mathrm{G}, \mathrm{T}, \mathrm{L}$ \\
\hline 26 & Stender potting soil & $\mathrm{M}$ & C & $100 \% \mathrm{Hh}(\mathrm{H} 3-\mathrm{H} 5, \mathrm{H} 5-\mathrm{H} 7), \mathrm{T}$ \\
\hline 27 & Frux with natural clay & $\mathrm{H}$ & C & $\mathrm{Hh}, \mathrm{T}$ \\
\hline 28 & Euflor, plantahum univ. & $\mathrm{H}$ & $\mathrm{C} / \mathrm{F}$ & $\mathrm{Hh}(\mathrm{H} 3-\mathrm{H} 5), \mathrm{S}, \mathrm{T}$ \\
\hline 29 & Kuhlmann potting soil & M & $\mathrm{F}$ & $82 \%$ Hh, $10 \%$ G, 5, 5\% S, 2.5\% T \\
\hline 30 & Grüne Welle, BayWa Ag & M & C & $\mathrm{Hh}(\mathrm{H} 3-\mathrm{H} 6), \mathrm{T}$ \\
\hline 31 & Raiffeisen Gartenkraft & M & C & $97 \% \mathrm{Hh}(\mathrm{H} 3-\mathrm{H} 8), \mathrm{T}, \mathrm{Ca}, 0.07 \% \mathrm{Gu}$ \\
\hline 32 & Cuxin, for container plants & $\mathrm{H}$ & C & $\mathrm{Hh}(\mathrm{H} 3-\mathrm{H} 4, \mathrm{H} 5-\mathrm{H} 6), \mathrm{Co}, \mathrm{T}$ \\
\hline 33 & DCM Cuxin, peat-free & $\mathrm{H}$ & C & $100 \%$ C \\
\hline 34 & Neudohum, peat-free & $\mathrm{H}$ & C & $\mathrm{F}, \mathrm{C}, \mathrm{T}$ \\
\hline 35 & Schomaker, garden product & $\mathrm{M}$ & C & $100 \% \mathrm{Hh}$ \\
\hline 36 & Pro-green-BK & kA & $\mathrm{C} / \mathrm{F}$ & $30 \% \mathrm{Hh}, 40 \%$ Co, 30\% P \\
\hline
\end{tabular}

Recommended application: $\mathrm{C}$ - container, $\mathrm{F}$ - open field, P/F - pot and open field Ingredients: $\mathrm{Hh}$ - bog peat; $\mathrm{H}$ - degree of decomposition, $\mathrm{G}$ - garden residual and compost, $\mathrm{F}$ - forest residual, T - clay, S- sand, L - loam, P - perlite, Co - coir (coconut fibre), Ca - lime, Gu - guano; Price: $\mathrm{M}$ - medium, $\mathrm{H}$ - high, $\mathrm{KA}$ - no information.

2.3 SAMPLE PREPARATION: The measurements were executed using $250 \mathrm{~cm}^{3}$ substrate samples. The fresh substrate was poured into steel cylinders (diameter $8 \mathrm{~cm}$, height $5 \mathrm{~cm}$, cross sectional area $50 \mathrm{~cm}^{2}$ ) and pre-treated with a uniform mechanical upload of $0.2 \mathrm{~kg} \mathrm{~cm}^{-2}=0.02 \mathrm{MPa}$.. The preparation was carried out in two steps. First the cylinder was filled two-thirds full and the load was held for one minute. Second, the cylinder was filled to the brim with substrate, a second cylinder was put on the 
top, this was filled half-full and all the substrate was compacted again for one minute. The sample was trimmed and saturated. After saturation, the sample was trimmed again and it was ready for the further hydraulic measurements.

2.4 HYDRAULIC MEASUREMENTS: The substrate water retention curve ( $p F$ curve) and the unsaturated hydraulic conductivity function (K-function) were measured simultaneously using the Extended Evaporation Method (EEM, Schindler et al., 2010) and the HYPROP device (HYdraulic PROPerty Analyser). The measurement was executed on $250 \mathrm{~cm}^{-3}$ substrate samples taken in steel cylinders. For the sample preparation see Paragraph 2.3. The substrate core was saturated with water and two tensiometers were inserted vertically from the bottom. The core was sealed at the bottom by clamping the cylinder with the HYPROP assembly. The core was placed on a balance, the substrate surface was exposed to free evaporation and the measurement started. The hydraulic gradient is calculated on the basis of the tension recordings in time intervals. The water flux is derived from the associated substrate water volume difference, equal to the sample mass difference. Individual points on the water-retention curve are calculated on the basis of the water loss per volume of the sample at time $\mathrm{t}$ and are related to the mean tension in the sample at this time. The unsaturated hydraulic conductivity $(\mathrm{K})$ is calculated according to the Darcy-Buckingham law. Using new cavitation tensiometers and applying the air entry value of the tensiometers' ceramic cup allows the range to be extended almost up to the wilting point (Schindler et al., 2010). Fig. 1 presents an example of hydraulic functions measured with the evaporation method (screenshot HYPROP fit software, UMS 2015). Capillarity is important for the movement and the distribution of the water in the substrate. The hydraulic conductivity was used to calculate the capillary height (z) based on Darcy's law (Eq. 1) for a $5 \mathrm{~mm} / \mathrm{d}$ flow rate (q) (Schindler and Dannowski 1982). The lower boundary was the ground water table. The upper boundary condition was defined at a tension of $1000 \mathrm{hPa}$.

$$
z=\int_{0}^{\psi} \frac{d \psi}{\frac{q}{K(\psi)}+1}
$$

Figure 1. Data points of the water retention curve, left, hydraulic conductivity as function of pF, middle and hydraulic conductivity as function of $\Theta$, right, as examples for HS no. 4, see Table 1, screenshot (HYPROP fit software, UMS 2015)
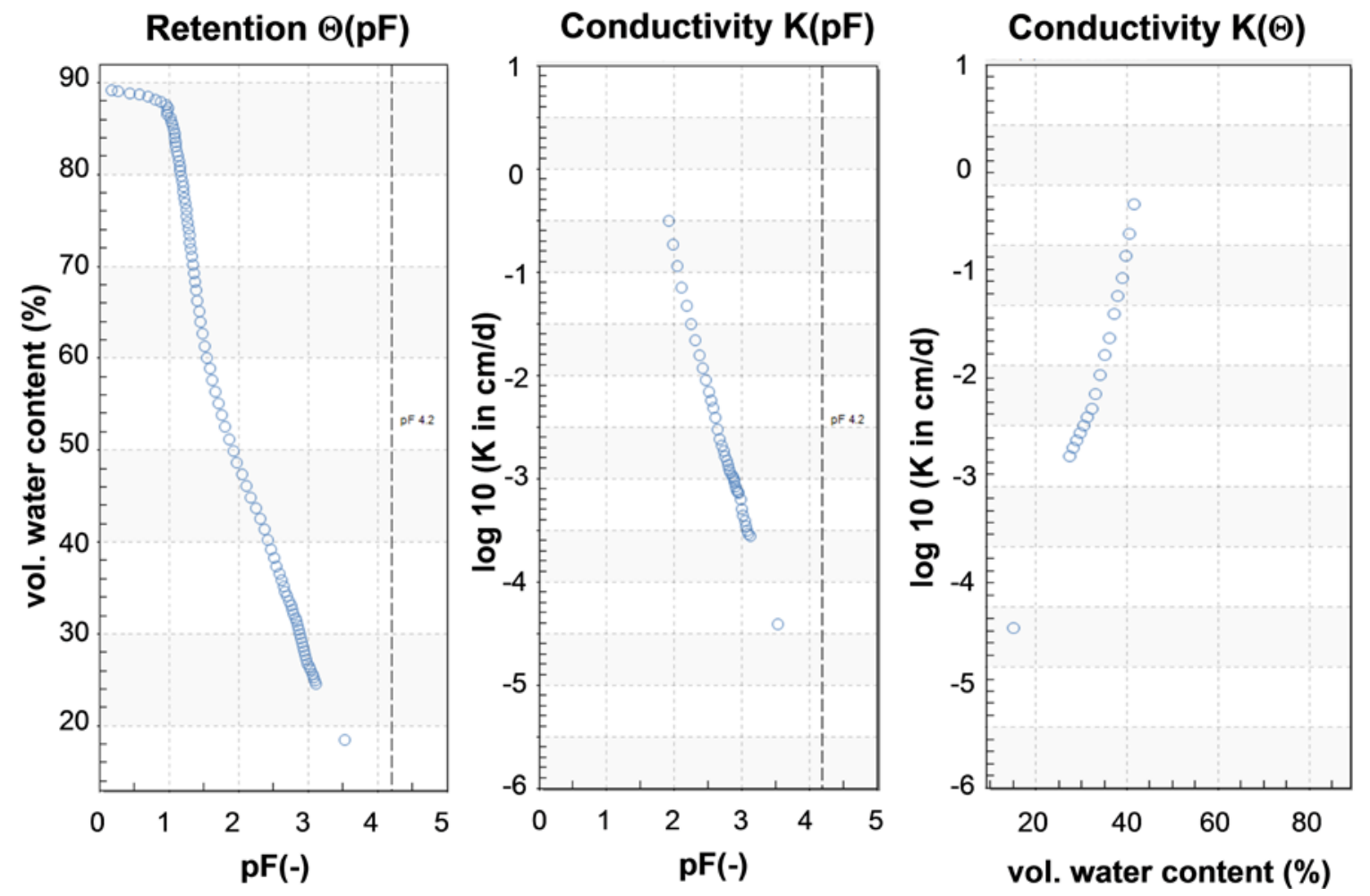
The shrinkage of the substrate sample (change in the sample diameter and height) was observed at distinct times during the EEM measurements. At the end of EEM and after oven drying $\left(105^{\circ} \mathrm{C}\right)$ the sample diameter and height were accurately measured with a sliding caliper and the volume of the sample was calculated. Further methodological details are given in Schindler et al. (2015a).

The wetting time was measured using the Water Drop Penetration Time Method (WDPT) (van 't Woudt, 1959, Beardsell et al., 1982, Schmidt, 1995, Blanco-Canqui and Lal, 2009). Starting with the fresh substrate material, one drop of water was added to the substrate and the water penetration time was measured. The test was repeated after $4 \mathrm{~h}$ and $24 \mathrm{~h}$ of free evaporation and with oven-dry substrate $\left(105^{\circ} \mathrm{C}\right)$.

3. STRUCTURE AND CONTENT OF THE DATABASE: The database presents all the relevant hydraulic properties of the substrates under study in detail. The database includes soil hydrological data (raw data) and additional information to the horticultural substrate such as the amount and decomposition status of bog peat, the recommended application and price level, the kind and amount of ingredients and information on the shrinkage behaviour, the capillarity and the rewetting properties. The dry bulk density was measured for each sample under study. The structure of the database is according to Table 2.

Table 2. Database content and structure

\begin{tabular}{ll}
\hline Work sheet & Information and data \\
\hline Basic data & HS ID- Horticultural substrate ID \\
& Recommended application \\
& Price level \\
& X- ash content in \%, burning at $650^{\circ} \mathrm{C}$ (DIN 18128, 2002) \\
& Hh- percentage of bog peat \\
& H- degree of decomposition (van Post, 1922) \\
& Coir in \% \\
& Compost in \% \\
& Perlite in \% \\
& Clay in \% \\
& Minerals in \%- sand, loam, lime stone \\
& Sdry- shrinkage in \% of the oven dry (105 $\mathrm{C}$ ) sample \\
& CR5- capillary height in cm of a 5 mm/d rate \\
& WT4- wetting time in sec. after 4 hours free evaporation \\
& Note: 1 in the database for coir, compost, perlite, clay and \\
& mineral stands for "is added". In this case no information on the \\
& amount in \% was given at the package. \\
\hline Dry bulk density & HS ID \\
& ID- Sample ID \\
& Dry bulk density of the sample in g/cm ${ }^{3}$ \\
\hline Soil water retention function & HS ID \\
& ID- Sample ID \\
& Value pairs: pF (-) and water content(vol\%) \\
\hline Unsaturated hydraulic & HS ID \\
conductivity as function of pF & ID- Sample ID \\
& Value pairs: pF (-) and log10K for K-hydraulic conductivity in \\
& cm/d \\
\hline Unsaturated hydraulic & HS ID \\
conductivity as function of $\Theta$ & ID- Sample ID \\
& Value pairs: water content (vol\%) and log10K for K-hydraulic \\
& conductivity in cm/d \\
\hline
\end{tabular}

The data show great variability between the substrates. The saturated water content varied between 78.8 and $90 \mathrm{vol} \%$ (on average $84.5 \mathrm{vol} \%$ ) and the permanent wilting point reached values between 7.9 and $20.9 \mathrm{vol} \%$ (on average $14.1 \mathrm{vol} \%$ ). The data were used to evaluate the hydraulic performance of horticultural substrates (Schindler et al., 2015b).

4 CONCLUSIONS: The Extended Evaporation Method (EEM, Schindler et al., 2010, Schindler et al., 2015a) was successfully used to quantify the hydraulic properties of horticultural substrates. The 36 
substrates under study provide a small overview of the hydraulic range of commercial horticultural substrates for horticultural applications. Data access under DOI 10.4228/ZALF.2015.278.

Other substrates and substrate mixtures, with bog peat from different parts of the world (Canada, Estonia, Finland and others) and various alternative ingredients can and should be analysed. The proposed method provides a simple and practicable solution.

5 ACKNOWLEDGEMENTS: We would like to thank Dr. J. Pilz, Regina Schmitt and Liane Laacke from the ZALF, Department of Landscape Information Systems for their assistance.

\section{REFERENCES}

Al Naddaf O, Livieratos I, Stamatakisa A, Tsirogiannisb I, Gizasb G, Savvasc D. 2011. Hydraulic characteristics of composted pig manure, perlite, and mixtures of them, and their impact on cucumber grown on bags. Sci. Hortic. 129: 135-141.

Beardsell DV, Nichols DG. 1982. Wetting properties of dried-out nursery pot media. Sci. Hortic. 17: 49-59.

Bibbiani C, Campiotti CA, Incrocci L. 2014. Estimation of hydraulic properties of growing media with a one-step outflow technique. International Symposium on Growing Media and Soilless Cultivation. Acta Hortic. 1034: 319-325.

Blanco-Canqui H, Lal R. 2009. Extent of soil water repellency under long-term no-till soils. Geoderma. 149: 171-180.

Caron J, Pepin S, Periard Y. 2014. Physics of growing media in green future. Proc. IS on Growing Media \& Soilless Cultivation. Acta Hortic. 1034: 309.-317.

DIN EN 13041, 2012. Bodenverbesserungsmittel und Kultursubstrate- Bestimmung der physikalischen Eigenschaften- Rohdichte (trocken), Luftkapazität, Wasserkapazität, Schrumpfungswert, und Gesamtporenvolumen, Beuth Verlag GmbH, Berlin.

DIN EN 18128, 2002. Baugrund- Untersuchung von Bodenproben- Bestimmung des Glühverlustes. Beuth Verlag GmbH, Berlin. 1-12.

Heiskanen J. 1995. Physical properties of two-component growth media based on Sphagnum peat and their implications for plant-available water and aeration. Plant and Soil. 172: 45-54.

Raviv, M., Lieth, J.H. 2008. Soilless culture: Theory and practice. Elsevier Publications. London. 608 pages.

Ritsema CJ, Dekker LW. 1996. Water repellency and its role in forming preferred flow paths in soils. Aust. J. Soil Res. 34: 475-487.

Schindler U, Dannowski R. 1982. Untersuchungen zum kapillaren Wasseraufstieg aus dem Grundwasser 1. Mitteilung: Methodik zur Quantifizierung des kapillaren Wasseraufstiegs. Arch. Acker-Pflanzenbau Bodenkd. 26: 125-132.

Schindler U, Durner W, von Unold G, Müller L, Wieland R. 2010. The evaporation method - Extending the measurement range of soil hydraulic properties using the air-entry pressure of the ceramic cup. J. Plant Nutr. Soil Sci. 173: 563-572.

Schindler U, Doerner J, Müller L. 2015a. Simplified method for quantifying the hydraulic properties of shrinking. soils. J. Plant Nutr. Soil Sci. 178: 136-145.

Schindler, U., Müller, L. Eulenstein, F. 2015b. Hydraulic Performance of Horticultural Substrates. 1. Method for Measuring the Hydraulic Quality Indicators. Horticulturae. Special Issue "Quality Management of Organic Horticultural Produce 2015". Proceedings of: OMOH 2015 "The First International Symposium on Quality Management of Organic Horticultural Produce". Ubon Ratchathani. 6-9. Dec. 2015. Thailand. 212-220.

Schindler, U., Müller, L. 2015a. Hydraulic Performance of Horticultural Substrates. Horticulturae. 2. Development of an Evaluation Framework. Special Issue "Quality Management of Organic Horticultural Produce 2015". Proceedings of: OMOH 2015 "The First International Symposium on Quality Management of Organic Horticultural Produce". Ubon Ratchathani. 6-9. Dec. 2015. Thailand. 221-227.

Schindler, U., Müller, L. 2015b. Hydraulic Performance of Horticultural Substrates. Horticulturae. 3. Impact of Substrate Composition and Ingredients. Special Issue "Quality Management of Organic Horticultural Produce 2015". Proceedings of: OMOH 2015 "The First International Symposium on Quality Management of Organic Horticultural Produce". Ubon Ratchathani. 6-9. Dec. 2015. Thailand. 228-239.

Schmidt W. 1995. Einfluß der Wiedervernässung auf physikalischen Eigenschaften des Moorkörpers der Friedländer Großen Wiese. Zeitschrift für. Kulturtechnik und Landentwicklung. 36: 107-111. 
UMS GmbH Munich. 2015. HYPROP® - Laboratory evaporation method for the determination of pFcurves and unsaturated conductivity, online:

http://www.ums-muc.de/en/products/soil laboratory.html

Van 't Woudt BD. 1959. Particle coatings affecting the wettability of soils. J. Geophys. Res. 64: 263267.

Von Post L. 1922. Sveriges Geologiska Undersöknings torvinventering och nogra av des hittils vunna resultat (SGU peat inventory and some preliminary results). Svenska Mosskulturforeningens Tidskrift. 36:1-37. 